\title{
Book Review: The Structural Prevention of Mass Atrocities: Understanding Risk and Resilience
}

\author{
Rhiannon S. Neilsen \\ University of New South Wales
}

Follow this and additional works at: https://digitalcommons.usf.edu/gsp

\section{Recommended Citation}

Neilsen, Rhiannon S. (2016) "Book Review: The Structural Prevention of Mass Atrocities: Understanding Risk and Resilience," Genocide Studies and Prevention: An International Journal: Vol. 9: Iss. 3: 180-182. DOI:

http://dx.doi.org/10.5038/1911-9933.9.3.1310

Available at: https://digitalcommons.usf.edu/gsp/vol9/iss3/15

This Book Review is brought to you for free and open access by the Open Access Journals at Digital Commons @ University of South Florida. It has been accepted for inclusion in Genocide Studies and Prevention: An International Journal by an authorized editor of Digital Commons @ University of South Florida. For more information, please contact digitalcommons@usf.edu. 


\title{
Book Review: The Structural Prevention of Mass Atrocities: Understanding Risk and Resilience
}

\author{
Rhiannon Neilsen \\ University of New South Wales \\ Sydney, Australia
}

The Structural Prevention of Mass Atrocities: Understanding Risk and Resilience

Stephen McLoughlin

New York: Routledge, 2014

188pp., US\$145 (hbk)

Reviewed by Rhiannon Neilsen

University of New South Wales, Australia

The Structural Prevention of Mass Atrocities opens with a clear logic of inquiry: why do some situations that exhibit the "root causes" of mass atrocities fail to culminate in carnage? Refining the book's trajectory further, what are the local and national sources of resilience that mitigate the risk of genocide? The first two chapters review the "root causes" of mass atrocities, and traces the history of prevention in the post-Second World War epoch. Two major conceptual limitations of structural prevention as it is presently understood in the literature come to the fore. First, despite the "root causes" of violence being considered predominantly local in nature, research on atrocity prevention emphasizes the role of international actors. This is not to dismiss the importance of international actors; rather, it is to illustrate that concentrating on external actors largely dismisses the risk-management mechanisms already being taken, or can be taken, by domestic actors. According to McLoughlin, the conceptual jump from "local problems" to "international solutions" common in the literature "accentuates the culture of external diagnosis and troubleshooting, and gives preventive action a paternalistic character" (24).

Second, existing approaches to structural prevention champion isolating and ameliorating the "root causes" of violence: "the 'cure' for genocide lies in diagnosing its causes" (43). McLoughlin states that this wrongly suggests a linear causal inevitability between risk factors and the onset of mass systematic violence. After all, "the perpetration of mass atrocities is rare - the exception rather than the norm" (25). McLoughlin identifies that these "root causes" discussed in the literature do not instigate carnages, but that carnages rarely occur in their absence. Therefore, although "root causes" are found to "create the conditions that are conducive to atrocities, these preconditions are not sufficient in and of themselves to directly cause such episodes of violence" (emphasis added, 25). Eschewing mere "external diagnosis and prognosis" (48), McLoughlin advocates that structural prevention should also encompass domestic policies and factors that promote stability and foster resilience. He thus turns to psychology, ecology, systems theory, and disaster management to chart risk factors, sources of resilience, and the "highly complex and deeply contextual" (48) dynamic of the two, as shown in Table 3.1 (51). This framework is then applied to Botswana, Zambia, Tanzania, and Zanzibar, all of which have remained immune to atrocities, notwithstanding factors that heighten the likelihood of genocide.

The context of McLoughlin's book is a scholarly reflection of existing approaches to genocide and mass atrocity prevention. 2015 marks the Responsibility to Protect (RtoP) at Ten: a decade on from the unanimous adoption of RtoP (with refinement) by member states of the United Nations at the 2005 World Summit. The first and foremost clause of RtoP stresses each individual state as bearing the primary responsibility to protect populations against mass atrocities. However, much of the ongoing debates in the literature have been preoccupied with the residual responsibility to discharge this duty: that is, with the responsibility of the international community to intervene if a government is manifestly failing to protect their citizens. Existing scholarly discourses regarding RtoP have thus been qualified by asking: who is to discharge this residual responsibility vis-àvis the ambiguously defined "international community"? How is this duty to be discharged? Is RtoP a moral imperative that must be discharged by the "international community," failing a legal UN Security Council resolution? These questions are fundamental to the furtherance of RtoP. Yet, 


\begin{tabular}{ll} 
Table 3.1 Framework for understanding the prevention of mass atrocities \\
\hline Risk factors of mass atrocities & $\begin{array}{l}\text { Factors that mitigate the risk of mass } \\
\text { atrocities }\end{array}$ \\
\hline Social divisions & Social cohesion \\
1 Religious, ethnic division & 1 Religious, ethnic cohesion \\
2 Social, economic or political & 2 Social, economic and political inclusion \\
3 History of genocide and/or mass & Good governance \\
atrocities & 3 Strong rule of law \\
4 Human rights violations & 4 A transparent and functioning \\
Weak or abusive regime & democratic system \\
5 Limited rule of law & executive \\
6 Limited democracy & Economic strength \\
Economic weakness & 6 Trade openness \\
7 Poverty and economic stagnation & 7 Equality of economic opportunity \\
8 Inequality of wealth and opportunities & 8 Sustained economic growth \\
9 Low economic interdependence & .
\end{tabular}

Figure 1.

comparatively little attention has been given to how the primary bearers of responsibility - local and national political entities of individual states - are to fulfill this duty. McLoughlin's book is motivated by this prevailing tendency in the literature. His contribution constitutes an instrumental shift in existing scholarly trends by reorienting the focus of prevention back toward the practices and policies of local and national actors. In other words, this book departs from the current climate of scholarly debate that concentrates on the "international community," and focuses attention to what processes individual states, as the foremost bearers of responsibility, can implement to avert mass atrocities. Such an academic departure is well timed to the current revisionary lens being applied to structural prevention and RtoP at Ten.

McLoughlin presents a genuine review of the proposed framework in light of each case study. In doing so, the reader is provided with a more sophisticated analysis, wherein McLoughlin admits there were processes "not explicitly identified in the framework [originally] deployed" (118) that assisted local and national actors in achieving greater prosperity, diversity and inclusion. Following this review, McLoughlin realizes the importance of charismatic, inaugural leaders espousing inclusive ideologies, and - more peripherally - smooth transitions toward independence coupled with cordial relations with British colonizers as factors that mitigate risk and foster resilience. This scrutiny, in turn, points to McLoughlin's transparency regarding method and argument, reaffirming that the framework is, far from being a final product, an avenue for continuous development. Merit is thus found in the soundness of his methodological approach, meticulous synthesis and commentary of existing notions of structural prevention, and exhaustive research into states that, due to "the lack of interest in the causes of peace in academic research" (165), have received fairly little coverage. The Structural Prevention is clear and coherent, guiding the reader through McLoughlin's train of logic and argument.

Unfortunately, there are a number of limitations that slightly weaken the overall conviction of The Structural Prevention of Mass Atrocities. Firstly, McLoughlin leaves readers wanting further clarification regarding the complex dynamic between risk and resilience: how many processes that stimulate resilience and stability are needed to offset risk? Are some resilience factors more salient than others; are some risk factors more perilous than others? What conditions need to be present for populations to be receptive to leaders with inclusionary ideologies? Greater confidence could have been afforded to the framework had such questions been acknowledged and interrogated. Secondly, McLoughlin's framework would have benefited from an analysis of case studies outside of new-born, post-colonial African states. The cases investigated have commonalities that unveiled additional factors for prevention, as discussed previously. However, these factors were specific to 
backdrop of African struggles for independence, to states where "the process of decolonization [were] characterized by amicable relations with British colonial administrators" (158), and to states with inaugural leaders in a post-colonial era. An analysis of dissimilar, non-African cases would have strengthened the framework's universal applicability, and perhaps yielded different, auxiliary processes that encourage resilience. Thirdly, McLoughlin identifies that the conditions that foster stability were often the same as, or were little distinct from, those that heightened risk or created negative consequences. That is, "the relationship between risk and resilience is not always a matter of distinct risk factors and mitigating factors" (93). Speaking of Botswana, "the incorporation of eight major chieftaincies into the House of Chiefs fostered national unity, but also marginalized the non-Tswana tribal groups. This exclusion further entrenched ethnic division in the country" (93). Similarly, Kaunda's reordering of key positions in the Zambian government and public sector prevented ethnic division, however it also increased "presidential powers, to the extent that [Kaunda] banned opposition parties and rendered parliament impotent... As a result, the public services...became severely hampered in the 1980s, provoking protests and riots by the decade's end" (118). While this observation illuminates the conceptual complexity inherent in the relationship between risk and resilience, it also points to practical dilemmas for political actors in terms of designing and implementing preventative policies. How are policy makers to know which resilience factors to augment, if each can also return intensified risk? McLoughlin falls short of acknowledging the practical difficulties that arise from this observation, leading the reader to conclude that each resilience factor is a deeply contextual, double-edged sword to be installed with caution and assiduous supervision.

This book is intended for students, scholars, and policy makers working toward effective genocide prevention strategies. Indeed, knowledge and diagnosis of early warning signs is paramount to the prevention of mass carnage. However, as McLoughlin points out, prevention literature that stresses only early warning and the role of international actors ultimately neglects the local and national processes that mitigate risk and foster stability. Current approaches to prevention therefore fall short of realising valuable policies of resilience that have successfully circumvented genocide in the past. McLoughlin's volume is envisioned for scholars and political actors, with the aim of extending the "prevention paradox" to include not just what goes wrong (identifying and responding to root causes/risk factors/early warnings of mass atrocities), but also what goes right (factors that mitigate risk, canvasses avenues of resilience, and encourages stability). In short, McLoughlin's The Structural Prevention of Mass Atrocities inaugurates a fresh, albeit nascent, approach to genocide prevention-one that is an important timely read for all those engaged, practically or theoretically, in peace and conflict studies. 